\title{
MAGNESIUM ALLOYS: A REVIEW OF APPLICATIONS
}

\section{MAGNEZIJEVE ZLITINE: PREGLED UPORABE}

\author{
Saravanan Annamalai*, Suresh Periyakgoundar, Sudharsan Gunasekaran \\ Department of Mechanical Engineering, Sona College of Technology, Salem, 636 005, India \\ Prejem rokopisa - received: 2019-03-22; sprejem za objavo - accepted for publication: 2019-07-13
}

doi:10.17222/mit.2019.065

\begin{abstract}
Reducing the weight of a vehicle is an important factor in fuel economy, addressing basic requirements and customer needs Magnesium alloys are promising for automotive, aerospace and medical applications, because of their low density and very good strength, as well as high bio-compatibility. However, many technical and commercial reasons limit their usage and applications in automobile components, particularly their low stiffness and poor corrosion performance. Following a brief review of the latest trends in the utilization of magnesium alloys in the automobile industry, this paper describes all the other difficulties when using magnesium alloys. A discussion of the manufacturing process, increasing the anti-corrosion properties, the application of $\mathrm{Mg}$ alloys based on a FE analysis and cost is presented. This review leads to the specific development and better utilization of magnesium alloys.
\end{abstract}

Keywords: magnesium alloys, application and design, service performance, cost, light weighting

Zmanjšanje mase vozila je pomemben faktor pri optimiziranju porabe goriva glede na zahteve uporabnikov in osnovne okoljske zahteve. Magnezijeve zlitine so obetaven material za uporabo v avtomobilih, letalih in medicinskih napravah, ker imajo nizko gostoto, dokaj dobro trdnost in visoko biokompatibilnost. Vendar pa njihovo uporabnost za avtomobilske komponente omejujejo mnogi razlogi tehnične in komercialne narave. Predvsem je to majhna togost in slaba odpornost proti koroziji. V kratkem pregledu avtorji navajajo najnovejše trende uporabe magnezijevih zlitin v avtomobilski industriji in vse spremljajoče težave, ki nastopijo pri njihovi uporabi. V razpravi o procesu njihove izdelave, se avtorji osredotočajo na povečanje njihovih antikorozijskih lastnosti in uporabo magnezijevih zlitin, z analizo na osnovi končnih elementov (FE) in stroškov. Članek naj bi bil prispevek $\mathrm{k}$ določenemu razvoju in boljši uporabnosti magnezijevih zlitin.

Ključne besede: magnezijeve zlitine, uporaba in dizajn, sposobnost servisiranja, stroški, lahka vozila

\section{INTRODUCTION}

Due to low their density, good specific strength and superior damping capacity, magnesium alloys have been used in automotive, aerospace and medical applications. ${ }^{1,2}$ In particular, the wrought magnesium alloy, from the economic point of view, replaces traditional metal alloys in load-bearing components in automobile applications. Also, the magnesium alloy provides large weight savings compared with aluminum alloys. ${ }^{3,4}$ However, the cost of a magnesium alloy has been limited by its low strength, so the wrought $\mathrm{Mg}$ alloy can be used for better strength because it gives a pronounced grain refinement without pores and with a uniform composition distribution after the elongation process. ${ }^{5,6}$ In recent years, a new generation of bio-gradable metallic materials like magnesium alloys have been used. This is also called a revelatory material for biomedical applications (e.g. as a bone implant material) because of its reasonable strength and high biocompatibility. ${ }^{7}$

Normally, human bone is composed of a matrix $(30 w / \%))$, minerals $(60 w / \%)$ and water $(10 \%))$. Metals with good compatibility such as platinum, stainless steel and titanium alloys are traditionally used as implants in fracture surgeries. Nowadays, magnesium hydroxy-

*Corresponding author's e-mail:

ansyssaran@gmail.com (Saravanan Annamalai) apatite matrix composites have been used for bone and tooth materials for the human body. The magnesium is the lightest material (from $1.74 \mathrm{~g} / \mathrm{cm}^{3}$ to $2.0 \mathrm{~g} / \mathrm{cm}^{3}$ range), being $77 \%$ lighter than steel and $33 \%$ lighter than aluminum. The material engineer say thanks to the magnesium alloy because of its great strength-to-weight ratio. In automotive applications, it shows better performance due to its stiffness, high vibrational absorption capacity and excellent cutting performance. ${ }^{8-18}$ But in practical applications, while it is subjected to cyclic structural component usually affected by corrosion attack, this leads to corrosion fatigue failure under non-corrosive environments, while fatigue failure occurs at stress variations below the designed values. ${ }^{19,20}$ But the fatigue strength of $\mathrm{Mg}$ alloys is very good in the air, it is almost satisfactory in industrial standards..$^{21,22}$ When compared with the aluminum corrosion resistance of modern high-purity magnesium alloys, they are better than that of conventional aluminum die-cast alloys. However, it has some mechanical/physical disadvantages that require a unique design for automobile part applications.

Vibrations occur when a body is subjected to any arrangement of forces. In other words, high intensities of strain, stress and noise are set up in the body as a result of vibrations. Vibrations in different structures and different materials occur at different frequencies. If a 
structure vibrates at frequencies higher or closer to the natural frequency of the component, the vibration may be exponentially higher. Moreover, it causes failure of the component. A Mg alloy offers a good specific strength, high damping capacity and very good energy-absorption capacity. M Eatson et al. ${ }^{23}$ made a comparison analysis of the energy absorption of $\mathrm{Mg}$ alloys with $\mathrm{Al}$ alloys and steel, and finally concluded that the $\mathrm{Mg}$ alloy has a better energy-absorption capacity when compared to $\mathrm{Al}$ and steel. D. Wan et al. ${ }^{24}$ investigated the damping capacity of $\mathrm{Mg}$ alloys at both room and elevated temperatures, the results show that the $\mathrm{Mg}$ alloy exhibits good damping capacity. However, from the perspective of engineering applications, $\mathrm{Mg}$ alloy structures are frequently simultaneously subjected to two or more numbers of different kinds of load, rather than a single load. Z. Ma et al. ${ }^{25}$ investigated the elastic-plastic bending properties of the AZ31b-Mg alloy using the combined load method, and finally concluded that the $\mathrm{Mg}$ alloy could reach a maximum deflection under different loading condition.

For low-cycle fatigue behavior of $\mathrm{Mg}$ alloys in between solution treated $\left(\mathrm{T} 4: 540{ }^{\circ} \mathrm{C} \times 10 \mathrm{~h}\right)$ and peak aged (T6: $540{ }^{\circ} \mathrm{C} \times 10 \mathrm{~h}+200{ }^{\circ} \mathrm{C} \times 14 \mathrm{~h}$ ) NZ30K alloy (Mg-3Nd-0.02Zn-0.5Zr) produced after the peak aged treatment exhibits its higher yield stress, ultimate tensile stress and cyclic hardening than the solutionized alloy, which is mainly due to the higher matrix strength provided by the precipitate strengthening. ${ }^{26}$ At the same stress amplitude the T4 treated alloy with higher hysteresis energies experienced more fatigue damage than the T6 treated alloy. For high cycle fatigue behavior of $\mathrm{Mg}$ alloys like hot-rolled AZ31 investigated at high frequencies $(97.3 \mathrm{~Hz})$ with different stress amplitudes (50 MPa, $60 \mathrm{MPa}, 70 \mathrm{MPa}, 90 \mathrm{MPa}, 110 \mathrm{MPa}$ ) for fatigue test using tension and compression loads at room temperature. ${ }^{27}$ The yield strength is higher than that of compression. Also, it leads to a catastrophic fracture after a particular number of cyclic loads, the fatigue behavior of $\mathrm{Mg}$ and its alloys further investigation should be needed for safety design purposes. ${ }^{28,29}$

From the manufacturing point of view, $\mathrm{Mg}$ and its alloys for automotive applications are usually made via casting. This casting method affords very good design flexibility and giving part integration there by a low "system" cost. The process technology for die casting $\mathrm{Mg}$ alloys will be developed and employed for manufactured components for automobiles. ${ }^{30}$ In the $\mathrm{Mg}$ sheet manufacturing process available for automotive components in the way of the elevated temperature forming process and conventional stamping process, there is some need for the new primary process (e.g., stamping) and secondary process (e.g., hemming). Table 1 shows the application of $\mathrm{Mg}$ alloys in the automobile industry.

\section{AN OVERVIEW OF Mg ALLOYS}

To analyze the properties of $\mathrm{Mg}$ alloys it is necessary to describe the sources, classification, and manufacturing process and advantages, disadvantages based on manufacturing process and applications as well as the mechanical properties and thermal properties.

\subsection{Sources and manufacturing process for Mg alloys}

Magnesium in an impure state was first obtained by Davy in 1808. The first commercial production of magnesium occurred in 1866 in Germany using a modified Bunsen electrolytic cell.

\subsubsection{Sources of magnesium ${ }^{31}$}

The sources from which magnesium is produced in commercially amounts are:

1. Natural brines $-\mathrm{MgCl}_{2}$

2. Sea water $-\mathrm{MgCl}_{2 \check{z}}+\mathrm{MgSO}_{4}-\mathrm{Mg}-0.13 \%$

3. Magnetite $-\mathrm{Mg} \mathrm{CO}_{3}-\mathrm{Mg}-29 \%$

4. Dolomite $-\mathrm{Mg} \mathrm{Ca}\left(\mathrm{CO}_{3}\right)_{2}-\mathrm{Mg} 13 \%$

5. Brucite $-\mathrm{Mg}(\mathrm{OH})_{2}-\mathrm{Mg} 42 \%$

\subsubsection{Extraction process}

The main types of process for the extraction of metallic magnesium are the following (Figure 1).

The electrolyte method is the cheapest method and it is used extensively, its only disadvantage is that a cell feed of high purity is needed. In the thermal reduction method, it is very easy to operate, but it has some

Table 1: Application of Mg alloys in the car industry

\begin{tabular}{|c|l|l|}
\hline S. No & \multicolumn{1}{|c|}{ Company } & \multicolumn{1}{c|}{ Part } \\
\hline 1 & Transmission Casings & $\begin{array}{l}\text { Volkswagen, Audi, Mercedes Benz, BMW, Ford, Jaguar, Daewoo, Volvo, } \\
\text { Porsche }\end{array}$ \\
\hline 2 & Instrument Panels & GM, Chrysler, Ford (Ranger, Aero Star 1994), Audi, Toyota, Hyundai, Honda \\
\hline 3 & Cylinder Head Cover & $\begin{array}{l}\text { Dodge, Honda, Alfa Romeo, Daewoo, BMW, Ford, Isuzu, Volvo, Hyundai, } \\
\text { KIA, GM (Corvette) }\end{array}$ \\
\hline 4 & Steering Components & Ford, Chrysler (Jeep 1993), Toyota, BMW, Lexus, GM, Hyundai, KIA \\
\hline 5 & Seat Frame and Other Components & GM, Mercedes Benz, Lexus, Hyundai, KIA \\
\hline 6 & Oil pan & Ford, Chrysler (LH midsize 1993) \\
\hline 7 & Engine Block & BMW \\
\hline 8 & Wheels/Rims & GM, Toyota, Alfa Romeo, Porsche, AG (7.44 kG each), Marti Suzuki \\
\hline 9 & Induction Clutch pedal, brake pedal & GM (Cover North Star V-8,1992) \\
\hline 10 & Miscellaneous components & Alfa-Romeo (GTV-45 kG), Porsche (911-53 kG) \\
\hline
\end{tabular}




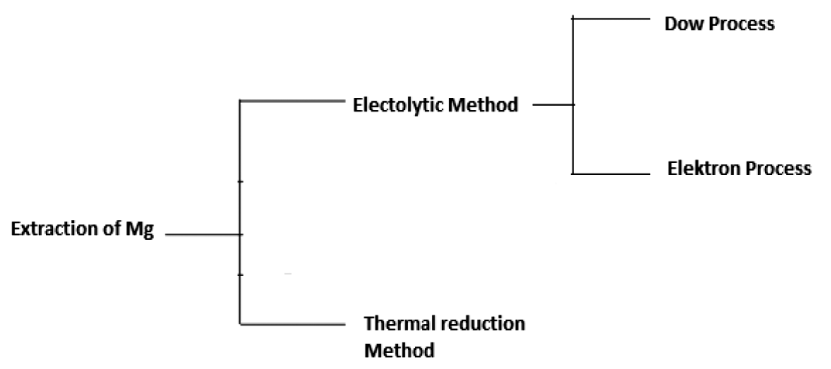

Figure 1: Extraction methods for Mg alloy

economic drawbacks, like high labor and maintenance costs.

\subsection{Classification of $\mathrm{Mg}, \mathrm{Al}$ and cast iron}

The classification of magnesium alloy, aluminum alloy and cast iron are given in Figures 2a to 2c. Cast iron comes under ferrous material and $\mathrm{Mg}$ and $\mathrm{Al}$ alloys come under non-ferrous materials.

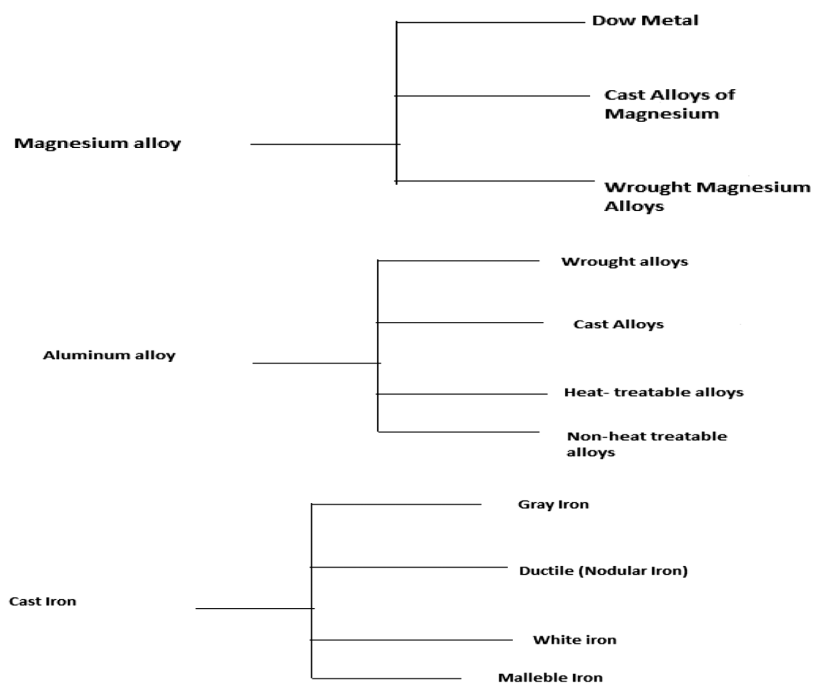

Figure 2: Materials classification: $\mathrm{Mg}$ alloy classification, $\mathrm{Al}$ alloy classification, cast iron classification

\subsection{Manufacturing process}

The magnesium alloy, usually produced by gravity and pressure die casting methods e.g., sand, permanent and semi-permanent mould and steel and investment casting. The method of selection of the production of magnesium alloy is based on many factors, e.g., the number of castings, type of properties, dimensions, applications and different types of size and shape. The AZ series and AM series alloys are manufactured using the pressure die-casting method. The following advantages and disadvantages were found from the pressure die-casting methods
2.3.1 Advantages of the pressure die-casting method
- High productivity
- High precision
- High-quality surface
- Fine cast structure
- Thin wall and complex structure possible
- In comparison to aluminum:
- $50 \%$ higher casting rate
- Can use steel ingots, which means a longer life
- Lower heat content, which means energy saving
- Good machinability
- Requires $50 \%$ of tooling costs
- High fluidity of melt

\subsubsection{Disadvantages of the pressure die-casting method}

- Entrapped gas pores as a result of high fill-up rate and thus solidification

- Thick walls cartable only to a limited degree

- Limited mechanical properties with cheaper die-casting alloys

- Limited range of alloys available

- Poor creep resistance due to fine grain-size cast microstructure

- Limited castability (and high cost) of creep resistant $\mathrm{Mg}-\mathrm{Al}-\mathrm{RE}$ alloys

- Heat treatment not possible

- Unsuitable for welding

\subsection{Mechanical and thermal properties of Mg alloys}

The density and specific stiffness (weight/deformation), strength (tensile strength, yield strength, etc.) of materials are very important factors in the design of weight-saving components in automobile and aerospace applications because of fuel consumption, energy

Table 2: Properties of $\mathrm{Mg}, \mathrm{Al}$ and cast iron ${ }^{32}$

\begin{tabular}{|c|l|c|c|c|}
\hline S. No & \multicolumn{1}{|c|}{ Property } & Magnesium alloys & Aluminum alloys & Cast iron \\
\hline 1 & Crystal structure & hcp & FCC & BCC \\
\hline 2 & Density $\left(\mathrm{MG} / \mathrm{m}^{3}\right)$ & $1.74-1.95$ & $2.5-2.9$ & $7.05-7.25$ \\
\hline 3 & Melting temperature $T_{\mathrm{m}}\left({ }^{\circ} \mathrm{C}\right)$ & $447-649$ & $475-677$ & $1130-1250$ \\
\hline 4 & Young's modulus $E(\mathrm{GPa})$ & $42-47$ & $68-82$ & $165-180$ \\
\hline 5 & Yield strength $(\mathrm{MPa})$ & $70-400$ & $30-500$ & $215-790$ \\
\hline 6 & Tensile strength $(\mathrm{MPa})$ & $185-475$ & $58-550$ & $350-1000$ \\
\hline 7 & Fracture toughness $(\mathrm{plane}-\mathrm{strain}) k_{\mathrm{cc}}(\mathrm{MPa} \sqrt{\mathrm{m}})$ & $12-18$ & $22-35$ & $22-54$ \\
\hline 8 & Thermal conductivity $\lambda(\mathrm{W} / \mathrm{m} . \mathrm{K})$ & $50-156$ & $76-235$ & $29-44$ \\
\hline 9 & Thermal expansion $\alpha\left(10^{-6} /{ }^{\circ} \mathrm{C}\right)$ & $24.6-28$ & $21-24$ & $10-12.5$ \\
\hline
\end{tabular}


savings and power limitations. When compared to other materials like aluminum and iron, the Young's modulus and the hardness are lower than aluminum and iron, as given in Table 1. But it is noted that the thermal coefficient factor is maximized. It is a very important factor to overcome the strength and modulus limitations.

From Table 2 and the above issues $\mathrm{Mg}$ alloys have distinct advantages over aluminum. These include better manufacturability and machinability, and because of the lower latent heat it gives faster solidification and a longer die life.

Because of its low mechanical strength, the pure magnesium alloy should be alloyed with some other elements, which gives better mechanical properties. For enhancing mechanical properties many commercial wrought $\mathrm{Mg}$ alloy systems have been developed, like the AZ, ZK and WE system. ${ }^{33,34}$ In China they are forming a large-scale industry to manufacture $\mathrm{Mg}$ alloy sheets in mass production. From previous research they are developing Mg alloy strengths and a new alloy system, and they are making, strengthening the grain refinement, precipitation and texture effects. Y. Kawamura et al..$^{35}$ produced a high-strength Mg alloy (Mg-Y-Zn) by rapidly solidified powder metallurgy that exhibits very good mechanical properties with a high range of tensile yield stress (TYS) of $610 \mathrm{MPa}$ and an elongation of $5 \%$. Also, the $\mathrm{Mg}$ alloy (Mg-8Gd-5Y-2Zn-0.6-Mn) that is extruded at $400{ }^{\circ} \mathrm{C}$ and aged at $200{ }^{\circ} \mathrm{C}$ gives a TYS of $322 \mathrm{MPa}$ and a UTS of $500 \mathrm{MPa} .^{36}$

\subsubsection{Advantages and disadvantages of magnesium alloys}

The advantages and disadvantages of magnesium alloys over conventional alloys like stain steel, aluminum, titanium, polymers and natural fibers are given below.

\subsubsection{Advantages of magnesium alloys are listed below}

- Lowest density of all metallic constructional materials

- Due to less density, it gives maximum acceleration

- High specific strength

- Good castability, suitable for high-pressure die casting

- Can be turned and milled at high speed

- Good weldability under a controlled atmosphere

- Much improved corrosion resistance using high-purity magnesium

- Readily available

- Compared with polymeric materials
- Better mechanical properties

- Resistant to ageing

- Better electrical and thermal conductivity

- Recyclable

- Compared with Aluminum

- Its latent heat is low, so more casting can be produced per unit time.

- Better surface quality and dimensionality.

- Smaller draft angle and curved surfaces.

- High specific strength (14\% higher than aluminum)

\subsubsection{Disadvantages of magnesium alloys are listed below}

- Low elastic modulus

- Limited cold workability and toughness

- Limited strength and creep resistance at elevated temperatures

- High degree of shrinkage on solidification

- High chemical reactivity

- In some applications there is a limited corrosion resistance.

\subsection{Corrosion resistance and biocompatibility of $\mathrm{Mg}$ alloys}

Magnesium alloys have poor corrosive resistance, which limits their usage in the automotive and aerospace industries. These alloys most likely suffer from atmospheric corrosion, which is an electrochemical process occurring on a metal surface covered with a thin electrolyte layer. ${ }^{37}$ Surface treatment is a practical way to enhance the surface properties of magnesium alloys to overcome the corrosion problems. ${ }^{38,39}$ Polymer coatings have been extensively used for the corrosion protection of metals due to their superior performance in an aggressive environment. ${ }^{40,41}$ Nowadays, magnesium alloys have been widely used in biomedical applications, like temporary orthopedic implants and cardiovascular stents. ${ }^{42,43}$ Also, the stress-shielding effect can be mitigated, since the Young's modulus of magnesium-based alloys matches that of human bone better than conventional bio-metals, such as stainless steel and titanium, and other alloys. ${ }^{44}$ However, degradation of magnesium alloys in an aggressive physiological environment is too rapid decay in a local alkaline environment, the excessive evolution of hydrogen bubbles and even the mechanical failure of the implant before the tissues heal completely. ${ }^{45,46}$ If the problems are solved, then its leads to a widening of the usage of magnesium alloys in

Table 3: Environmental resistance of $\mathrm{Mg}, \mathrm{Al}$ and cast iron

\begin{tabular}{|c|c|c|c|c|c|c|}
\hline S. No & Material & Flammability & Fresh water & Salt water & $\begin{array}{c}\text { Sun light } \\
\text { (UV) }\end{array}$ \\
\hline 1 & Mg alloys & Very good & Very good & Poor & Very good \\
\hline 2 & Al alloys & Good & Very good & Good & Very good \\
\hline 3 & Cast iron & Very good & Good & Average & Very good \\
\hline
\end{tabular}


biomedical engineering. The Table 3 describes the environmental resistance of magnesium alloys, aluminum alloys and cast iron.

\section{APPLICATION OF Mg ALLOYS BASED ON A FE ANALYSIS}

To investigate the mechanical behavior of $\mathrm{Mg}$ alloys and compare with $\mathrm{Al}$ and cast-iron materials, the following materials are used and FEA code ANSYS15.0 software was utilized. Because those three materials have very good mechanical properties among the $\mathrm{Mg}, \mathrm{Al}$ and cast-iron group of materials.

Table 4: Material properties of $\mathrm{Mg}, \mathrm{Al}$ and cast iron

\begin{tabular}{|c|l|c|c|c|c|}
\hline S. No & \multicolumn{1}{|c|}{ Properties } & Unit & $\mathrm{Mg}$ & $\mathrm{Al}$ & $\begin{array}{c}\text { Cast } \\
\text { iron }\end{array}$ \\
\hline 1 & Density & $\mathrm{KG} / \mathrm{m}^{3}$ & 1700 & 2700 & 7500 \\
\hline 2 & $\begin{array}{l}\text { Modulus of } \\
\text { elasticity (E) }\end{array}$ & $\mathrm{GPa}$ & 45 & 70 & 180 \\
\hline 3 & Poisson's ratio & - & 0.3 & 0.33 & 0.29 \\
\hline 4 & $\begin{array}{l}\text { Tensile yield } \\
\text { strength }\end{array}$ & $\mathrm{MPa}$ & 310 & 216 & 200 \\
\hline 5 & $\begin{array}{l}\text { Ultimate tensile } \\
\text { strength }\end{array}$ & $\mathrm{MPa}$ & 230 & 370 & 310 \\
\hline
\end{tabular}

The mechanical properties of all the three materials are given in Table 3. The materials and the compositions for all the three materials are given in Table 5. This study involves a comparison of three materials based on the different types of FE analysis, like bending, thermal, vibration and fatigue analysis with different loading conditions.

Table 5: Materials and composition

\begin{tabular}{|c|l|l|l|}
\hline S. No. & \multicolumn{1}{|c|}{ Alloy } & \multicolumn{1}{|c|}{ Name } & \multicolumn{1}{c|}{ Composition } \\
\hline 1 & Mg alloy & AZ61 & $\begin{array}{l}\text { Mg-Al-Zn-Mn-Si- } \\
\text {-Cu-Ni-Fe }\end{array}$ \\
\hline 2 & Al alloy & $\begin{array}{l}\text { Aluminum } \\
\text { 6061-T6 }\end{array}$ & Al-Mn-Mg-Si- -Cu-Cr \\
\hline 3 & Cast iron & ASTM Grade 40 & Fe-C-Si-Mn-P-S \\
\hline
\end{tabular}

\subsection{Nonlinear static analysis of $\mathrm{Mg}, \mathrm{Al}$ and cast iron}

For the nonlinear static analysis, the materials taken from Table 4 and FEA code ANSYS 15.0 software were used to find the stress-strain curves for all three materials in the analytical method. The loading condition and the dimension of the beam are given in Figure 3a.

The boundary conditions are:

- No of sub steps - 5

- Maximum no. of sub steps -100

- Minimum no. of sub steps - 1

The nonlinear static analysis was obtained In an analytical method and the stress value given in Figure 3b. Similarly, all the materials are analyzed with the analytical method using FEA and the values given the Figures 3c and 3d.
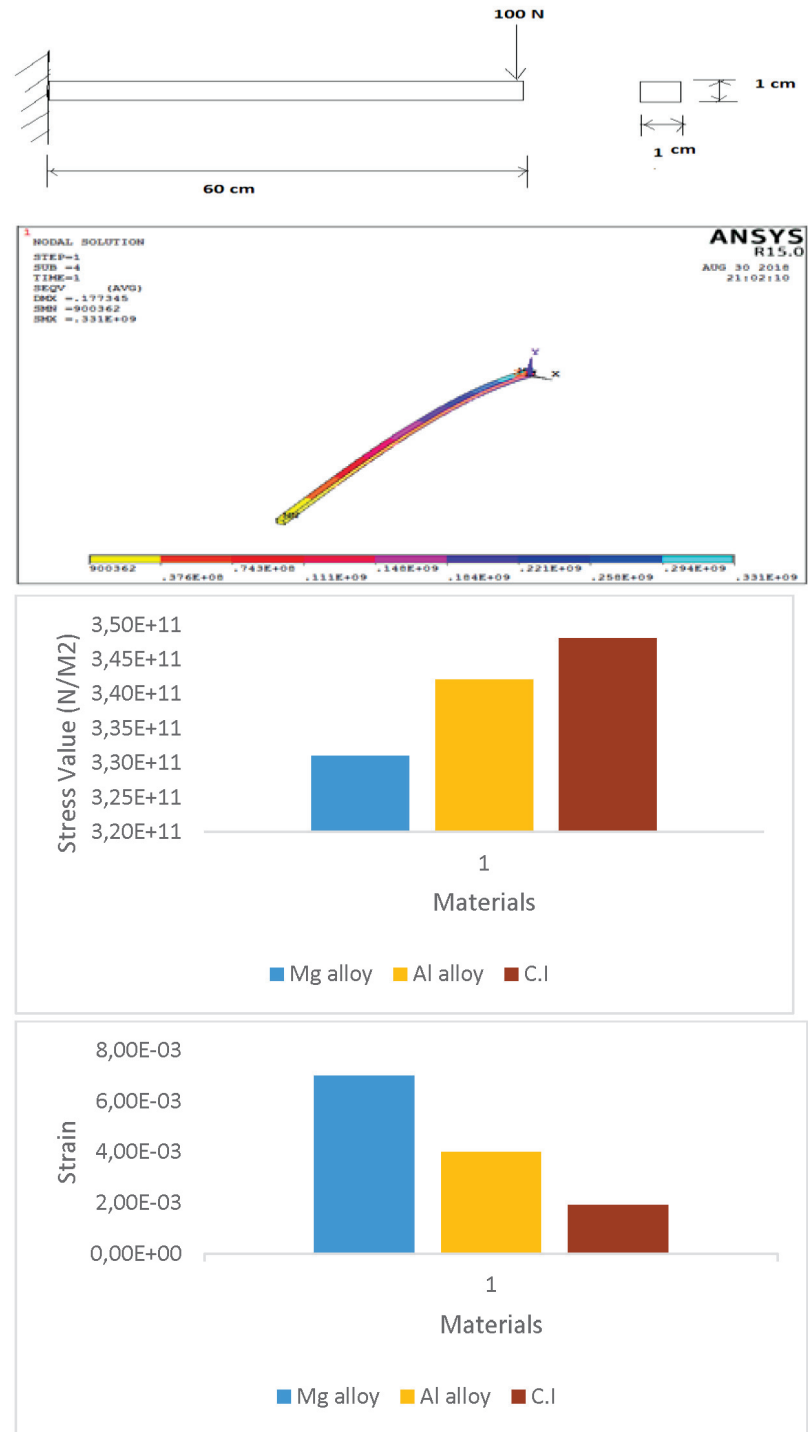

Figure 3: Nonlinear static analysis: a) CAD model for static load condition, b) stress analysis of $\mathrm{Mg}, \mathrm{c}$ ) stress curve, d) strain curve

The stress and strain values are taken from the analytical method and the bar charts are drawn, and it is shown in Figures 3c and 3d.

From the bar chart for stress for the $\mathrm{Mg}$ alloy, $\mathrm{Al}$ alloy and cast iron, it was observed that the stress value of the magnesium alloy was very low when compared to the other two materials, because of adding $\mathrm{Zr}$ material in the $\mathrm{Mg}$ alloy composition, so its applicable for high stress load application like fatigue load, etc. ${ }^{37}$ In the strain bar chart the strain values of the $\mathrm{Mg}$ alloy were much less when compared to other materials, and its revels that Mg alloys have very low stiffness, so that they are not suitable for heavy load application. Also, the magnesium alloy is not suitable for power train and gears and engine castings can be made because of its creep behavior. Considering the creep point of view the AE series of $\mathrm{Mg}$ alloys have better creep resistance when compared to the $\mathrm{AZ}$ series of $\mathrm{Mg}$ alloys. 


\subsection{Thermal analysis of $\mathrm{Mg}, \mathrm{Al}$ and cast iron}

To investigate the thermal properties of all the three materials, the following thermal analysis was carried out by an analytical method. The boundary-condition and temperature values as given in Figure $\mathbf{4 a}$ and materials for these analyses were taken from Table 4. The FEA code ANSYS 15.0 software was utilized in this analysis.

The temperature distribution along the $\mathrm{Mg}$ alloy material given in the Figure $\mathbf{4} \mathbf{b}$, it is clearly indicated that the temperature along the material starts from $100{ }^{\circ} \mathrm{C}$ to $500{ }^{\circ} \mathrm{C}$, also the distribution curve indicated
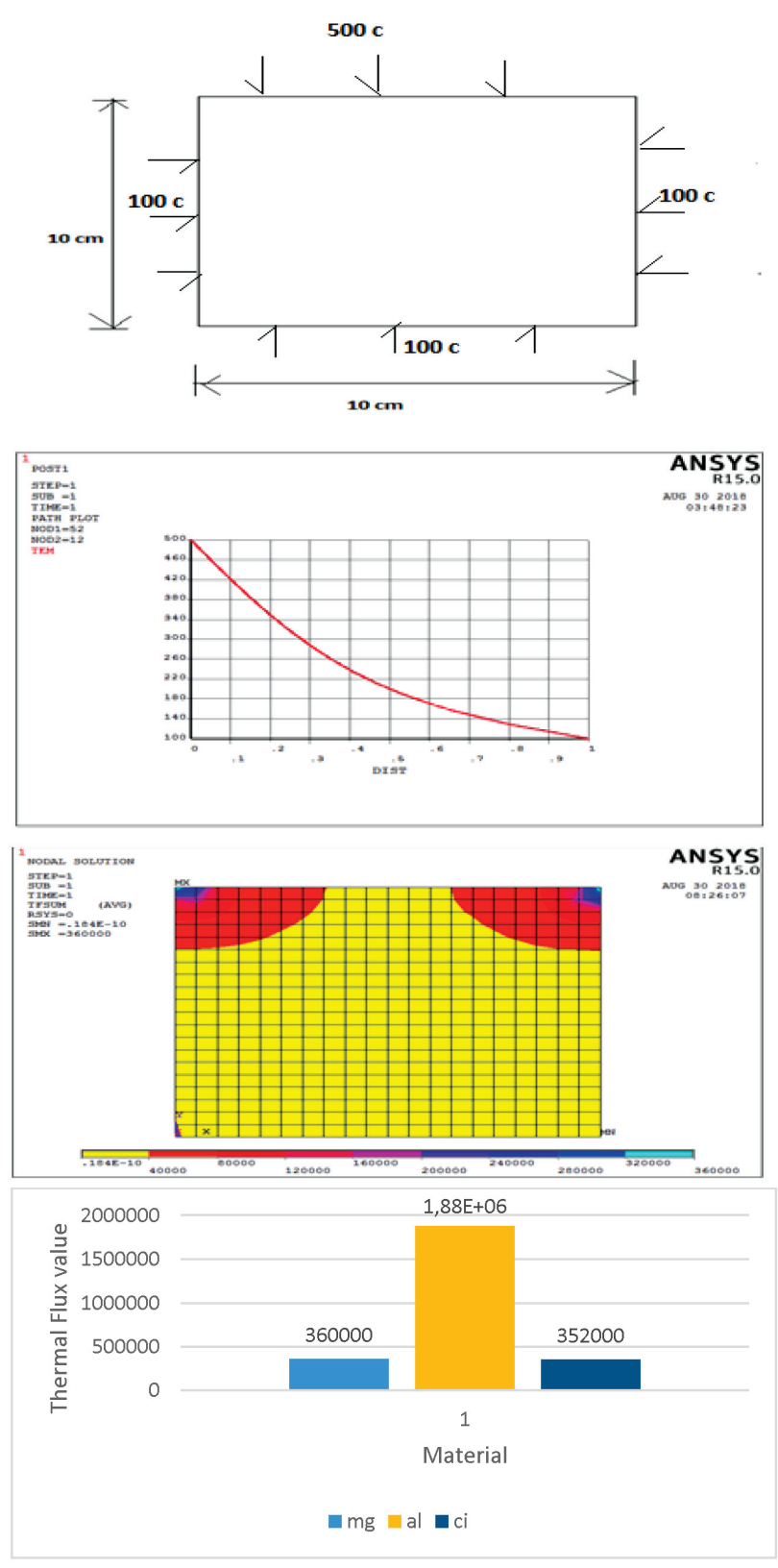

Figure 4: Thermal analysis: a) CAD-model for thermal load condition, b) temperature distribution curve (node number vs. temperature) for $\mathrm{Mg}$ alloy, c) thermal flux analysis of $\mathrm{Mg}$ alloy, d) thermal flux curve for all the three materials that the temperature distribution along the material is nonlinearly increased.

The thermal analysis of the $\mathrm{Mg}$ alloy is given in Figure 4c. It shows that the minimum heat flux value and the maximum heat flux value of the $\mathrm{Mg}$ alloy were occurring along the material.

The Figure 4d curve shows that the heat-flux value of the magnesium alloy is significantly lower than that of the $\mathrm{Al}$ alloy and it is slightly higher than that of the cast iron. The result revealed that the heat-resisting capacity of the $\mathrm{Mg}$ alloy has shown better than that of the Al alloy and nearly equal to the cast iron form that the $\mathrm{Mg}$ alloy is suitable for heat-resisting applications for gear-box housings and engine housings, etc.

\subsection{Vibration analysis of $\mathrm{Mg}, \mathrm{Al}$ and cast iron}

A vibration analysis is very important for predicting the damping capacity, vibration and noise control of the material. To investigate the damping capacity of all three materials the following boundary and loading conditions were utilized. To investigate the natural frequency and frequency under different static loading conditions for all the three materials, the following vibrational analysis was carried out using ANSYS15.0.

The material properties of all three materials were taken from Table 4 and the boundary condition was given in Figure 5a. From this analysis the damping capacity of all the three materials was found more over this study focus on the vibration response for all the three materials in the static loading condition.

The natural frequency of all the three materials was found from the vibration analysis and it is tabulated in Table 6.

Table 6: Natural frequency for $\mathrm{Mg}, \mathrm{Al}$ and cast iron

\begin{tabular}{|c|c|c|}
\hline S. No. & Material & Natural frequency $(\mathrm{Hz})$ \\
\hline 1 & Mg alloy & 23.38 \\
\hline 2 & Al alloy & 23.25 \\
\hline 3 & Cast iron & 22.0 \\
\hline
\end{tabular}

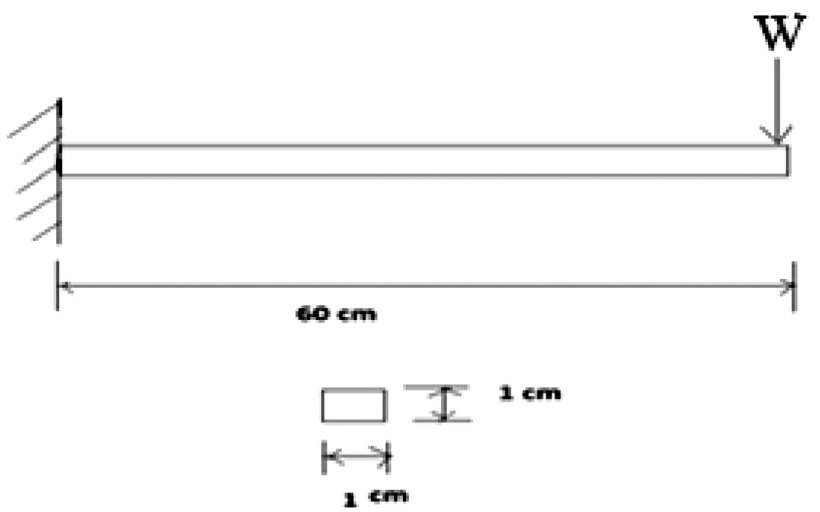

Figure 5: CAD model for static load condition 
From Table 6 it can be seen that the natural frequency of the $\mathrm{Mg}$ alloy and $\mathrm{Al}$ alloy are nearly the same, but the cast iron was significantly lower when compared to that of the other two materials. The frequency under different static loading conditions was obtained using a vibration analysis and it was tabulated in Table 7.

Table 7: Frequency under loading condition for $\mathrm{Mg}, \mathrm{Al}$ and cast iron

\begin{tabular}{|c|c|c|c|c|c|c|}
\hline S. No. & Material & \multicolumn{5}{|c|}{ Frequency ( Hz) } \\
\hline & & $100 \mathrm{~N}$ & $200 \mathrm{~N}$ & $300 \mathrm{~N}$ & $400 \mathrm{~N}$ & $500 \mathrm{~N}$ \\
\hline 1 & Mg alloy & 13.35 & 13.00 & 12.80 & 12.45 & 12.00 \\
\hline 2 & Al alloy & 13.25 & 13.00 & 12.80 & 12.50 & 12.15 \\
\hline 3 & Cast iron & 12.80 & 12.70 & 12.65 & 12.50 & 12.55 \\
\hline
\end{tabular}

From Table 7 it can be seen that if increasing the load then the frequency value of the $\mathrm{Mg}$ alloy goes down, when compared to the other two materials. The $\mathrm{Mg}$ alloy and $\mathrm{Al}$ alloy have nearly equal values under the loading condition, and it is revealed that both materials have nearly equal vibration-absorption capacity under the loading conations. Even though the $\mathrm{Mg}$ alloy and $\mathrm{Al}$ alloy gave similar results, the $\mathrm{Mg}$ alloy exhibits better vibration-absorption capacity than that of the Al alloy.

Figure 5 is drawn using the Table 4 values. It can be seen that the damping capacity of the $\mathrm{Mg}$ alloy was better than that of the other two materials. So the $\mathrm{Mg}$ alloy can be used for high-damping applications in automobile parts, like the connecting rod, engine mounting, and crank case box.

\subsection{Fatigue behavior of $\mathrm{Mg}$ alloys}

To improve the fatigue behavior of magnesium alloys in various fields, it is necessary to follow suitable processing methods and reduce the amount of residual twins. Twinning is one of the most important deformation mechanisms of magnesium alloys because of its hexagonal close packed (hcp) structure. ${ }^{47,48} \mathrm{~L}$. Jiang et al. ${ }^{49}$ mentioned the addition of zirconium $(\mathrm{Zr})$ can prolong the fatigue life, because $\mathrm{Zr}$-addition promotes grain refinement. Ni et al. ${ }^{50}$ improved the fatigue limit of an AZ91 magnesium alloy from $45 \mathrm{MPa}$ to $90 \mathrm{MPa}$ by using the friction-stir processing method. Yang and

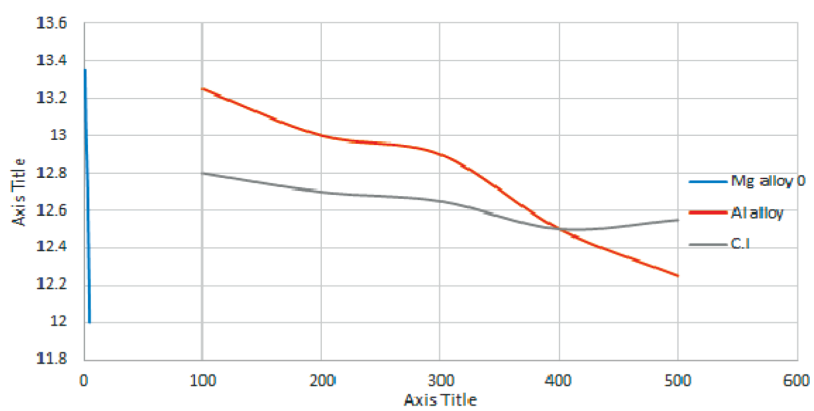

Figure 5: Damping capacity for all the three materials - vibration analysis co-authors found that the Mg-12Gd-3Y-0.5Zr alloy exhibits much better fatigue performance when compared to the AZ31 alloy by improving the grain refinement. They improved the fatigue limit on the AZ91 alloy from $45 \mathrm{Mpa}$ to $90 \mathrm{Mpa}$ by friction-stir processing. G. Huang et al. ${ }^{51}$ found that the Mg-12Gd-3Y-0.5 Zr magnesium alloy has better fatigue life than to that of the AZ31 alloy. Li et al. ${ }^{52}$ found that the peak-treated (T6) NZ30K alloy exhibits much higher fatigue strength when compared to a cast alloy. Considering the aluminum alloy group of materials, a cast aluminum alloy exhibits better stiffness when compared to steel. ${ }^{53}$

\subsubsection{Fatigue behavior of $\mathrm{Mg}, \mathrm{Al}$ and cast iron}

In automotive parts applications the fatigue is a significant property, so that the material should be analyzed for fatigue behavior. For this analysis the following materials are taken into consideration and listed Table 2. This is because these materials are very high strength among the alloy group of materials.

Using FEA analysis software ANSYS 15.0 was utilized to find the fatigue behavior. The fatigue values of all three materials are taken and plotted on the bar chart, and given in Figure 6b. Four load cases were applied at the free end of the beam for the fatigue analysis. The load step values and the size and shape of the beam for all the three materials are given in Figure $6 a$.

- $100 \mathrm{~N}$ at each corner. The time at the end of load step is $10 \mathrm{~s}$.

- $-100 \mathrm{~N}$ at each corner. The time at the end of load step is $20 \mathrm{~s}$.

- No. of cycles is $10^{7}$

The fatigue life of all the three materials was taken from the above analysis and the values are plotted in Figure 6b.
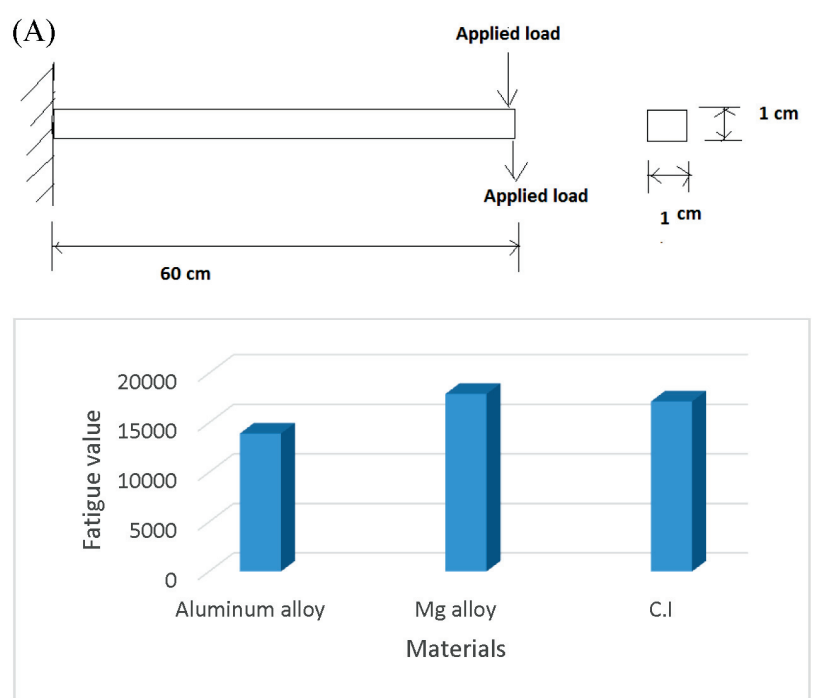

Figure 6: Fatigue analysis: a) CAD-model for fatigue load condition, b) fatigue value for $\mathrm{Mg}, \mathrm{Al}$ and cast iron 
In Figure $\mathbf{6 b}$ it is observed that the magnesium alloy exhibits a high fatigue value when compared to aluminum and cast iron. So it can be applicable for automobile spare parts, like the connecting rod and engine mounting and some other parts which are affected by a fatigue load.

\section{COST ANALYSES OF Mg, Al AND CAST IRON}

The higher cost is the major disadvantage of the magnesium alloys. In the U.S., Mg alloy sells for \$2.15 per pound, which is approximately double the price of aluminum alloys, and it is more expensive when compared to cast iron. ${ }^{54.55}$ Because of that, many of the mechanical components in automobiles, like hydraulic jack, levers and handles, are made of mild steel and cast iron. ${ }^{56}$ In India the cost of all the three materials in 2018 varies based on the composition that approximate cost given in Tables 4, 5 and $\mathbf{6}$ the cost variation of all the three materials given in the Figure 7. The price increasing of $\mathrm{Mg}$ alloys in India is because of the small market size and the limited number of sources. Considering world market, China is the largest producer, and they are manufacturing nearly $88 \%$ of the $\mathrm{Mg}$ alloy materials in the world.

Table 8: Cost analysis of magnesium $(\mathrm{Mg})$ alloy

\begin{tabular}{|c|c|c|c|}
\hline S. No. & Item description & Quantity (kg) & Price (INR) \\
\hline 1 & Magnesium alloy AM 70 & 1 & 2865.00 \\
2 & Magnesium alloy AM 80 & 1 & 2935.00 \\
3 & Magnesium alloy AM 90 & 1 & 2996.00 \\
\hline
\end{tabular}

Table 9: Cost analysis of aluminum (Al) alloy

\begin{tabular}{|c|c|c|c|}
\hline S. No. & Item description & Quantity (kg) & Price (INR) \\
\hline 1 & Aluminum alloy 2014A & 1 & 345.00 \\
2 & Aluminum alloy 6061 & 1 & 325.00 \\
3 & Aluminum alloy 7075 & 1 & 500.00 \\
4 & Aluminum alloy 2219 & 1 & 1000.00 \\
\hline
\end{tabular}

Table 10: Cost analysis of cast iron

\begin{tabular}{|c|c|c|c|}
\hline S. No. & Item description & Quantity (kg) & Price (INR) \\
\hline 1 & Heavy cast-iron castings & 1 & 100.00 \\
2 & Ductile cast-iron castings & 1 & 53.00 \\
3 & Cast-iron sand castings & 1 & 50.00 \\
\hline
\end{tabular}

The market values of all three materials were plotted in the bar chart in Figure 7. The cost of the Mg alloy is significantly higher when compared to the other materials in the Indian market because of less availability in India. During the term, the development of low-cost $\mathrm{Mg}$ alloy sheets compatible with slightly modified processing technic and equipment is available today. That new forming technique is capable of delivering $\mathrm{Mg}$ alloys, as per the requirement. There are several techniques and equipment is available in the manufacturing industry, like ICME tools, CAE tools, etc. Many of the methods and areas are not discussed in this paper.

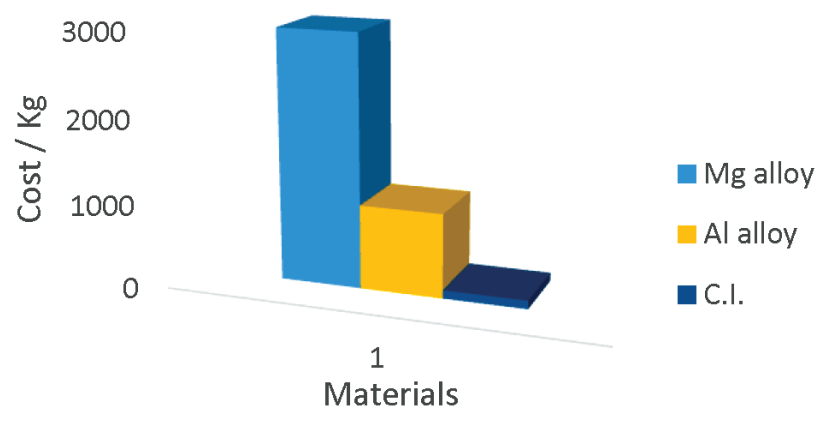

Figure 7: Cost analyses for $\mathrm{Mg}, \mathrm{Al}$ and cast iron

Moreover, there is substantial opportunity for innovation in the alloying, processing and integrating of magnesium alloys.

\section{CONCLUSIONS}

Based on the literatures from various research articles for magnesium alloys, light weighting, physical properties, fatigue strength, corrosion, biocompatibility and cost are analyzed. The following observations are made on the above literature survey and FEA analysis.

Magnesium alloys have become reliable and are in demand in the automotive, aerospace and biomedical applications.

From the FEA analysis, the result revealed that the $\mathrm{Mg}$ alloy is suitable for high stress, better damping capacity and fatigue load applications, moreover the heat-resisting capacity is significantly higher when compared to other materials.

It is very important to realize that the use of magnesium alloys requires an integrated approach between the user and the manufacturer to ensure suitable functionality and safety.

In the future we need a high-performance magnesium alloy with a greater corrosion resistance, a high fatigue strength, low prices, good biocompatibility, better stiffness and creep resistance, which requires more research and development.

Continuous research and development in magnesium alloys, like wrought magnesium alloy, is the key to the future of increased applications in the automobile and aerospace industries and biomedical applications.

The use of magnesium alloy will be continued in the future to help designers, engineers innovate and to take better vehicle performance further.

Finally, more innovations are needed in the research and development of $\mathrm{Mg}$ alloys.

\section{REFERENCES}

${ }^{1}$ W. J. Xia, Z. H. Chen, D. Chen, S. Q. Zhu, Microstructure and mechanical properties of AZ31 magnesium alloy sheets produced by differential speed rolling, Mater.Process, Technol, 209 (2009), 26-31, doi:10.1016/j.jmatprotec.2008.01.045 
${ }^{2}$ Y. C. Lin, X. M. Chen, Z. H. Lin, Investigation of uniaxial low cycle fatigue failure behavior of hot rolled AZ91 magnesium alloy, Int. J. Fatigue, 48 (2013), 122-132, doi:10.1016/j.ijfatigue.2012.10.010

3 B. L. Mordike, T. Ebert, Magnesium: properties-applications-potential, Mater. Sci. Eng. A., 302 (2001), 37-45, doi:10.1016/S09215093(00)01351-4

${ }^{4}$ H. Friedrich, S. Schumann, Research for a žžnew age of magnesium" in the automotive industry, J. Mater. Process. Technol, 117 (2001) 276-281, doi:10.1016/S09240136 (01)00780-4

${ }^{5}$ M. R. Barnett, Z. Keshavarz, A. G. Beer, D. Atwell, Influence of grain size on the compressive deformation of wrought $\mathrm{Mg}-3 \mathrm{Al}-1 \mathrm{Zn}$, Acta Mater, 52 (2004), 5093-5103, doi:10.1016/j.actamat.2004. 07.015

${ }^{6}$ K. Kubota, M. Mabuchi, K. Higashi, Processing and mechanical properties of fine-grained magnesium alloys, J. Mater. Sci, 34 (1999), 2255-2262, doi:10.1023/A: 100456120

M. Haghshenas, Mechanical characteristics of biogradable magnesium matrix composites: a review, Journal of Magnesium Alloys, 5 (2017), 189-201, doi:10.1016/j.jma.2017.05.001

${ }^{8}$ Y. F. Zang, X. N. Gu., F. Witte, Biodegradable metals, Mater, Sci, and Eng., 77 (2014), 1-34, doi:10.1016/j.mser.2014.01.001

${ }^{9}$ N. Tahreen, D. F. Zhang, F. S. Pan, X. Q. Jiang, D. Y. Li, D. L. Chen, Hot deformation and work hardening behavior of an extruded Mg-Zn-Mn-Y alloy, J. Mater. Sci. Technol, 31 (2015), 1161-1170, doi:10.1016/j.jmst.2015.10.001

${ }^{10}$ M. Kaseem, B. K. Chung, H.W. Yang, K. Hamad, Y. G. Ko, Effect of deformation temperature on microstructure and mechanical properties of AZ31Mg alloy processed by differential speed-rolling, J. Mater. Sci. Technol., 31 (2015), 498-503, doi:10.1016/j.jmst. 2014.08.016

${ }^{11}$ J. R. Dong, D. F. Zhang, J. Sun, Q. W. Dai, F. S. Pan, Effects of different stretching roots on microstructure and mechanical properties of AZ31B magnesium alloy sheets ,J. Mater. Sci. Technol., 31 (2015), 935-940, doi:10.1016/j.jmst.2015.07.011

${ }^{12}$ W. Y. Zhang, D. Y. Ju, H. Y. Zhao, X. D. Hu, Y. Yao, Y. J. Zhang, A decoupling control model on perturbation method for twin-roll casting magnesium alloy sheet, J. Mater. Sci. Technol., 31 (2015), 517-522, doi:10.1016./j.jmst.2015.01.005

${ }^{13}$ D. Sarker, J. Friedman, D. L. Chen, De-twinning and texture change in an extruded AM30 magnesium alloy during along normal compression, J. Mater. Sci. Technol., 31 (2015), 264-268, doi:10.1016/ j.jmst.2014.11.018

${ }^{14}$ F. S. Pan, M. B. Yang, X. H. Chen, A review on casting magnesium alloy: modification of commercial alloys and development of new alloys, J. Mater. Sci. Technol., 32 (2016), 1211-1221, doi:10.1016/ j.jmst.2016.07.001

${ }^{15}$ Y. Liu, H. Ren, W. C. Hu, D. J. Li, X. Q. Zeng, K. G. Wang, J. Lu, First- principles calculation of strengthening compounds in magnesium alloy : a general review, J. Mater. Sci. Technol., 32 (2016), 1222-1231, doi:10.1016/j.jmst.2016.04.003

${ }^{16}$ C. Q. Li, D. K. Xu, B. J. Wang, L. Y. Sheng, E. H. Han, Suppression Effect of Heat Treatment on the Portevin-Le Chatelier Phenomenon of Mg-4Li-6\% Zn-1.02\%Y Alloy, J. Mater. Sci. Technol, 32 (2016), 1232-1238, doi:10.1016/j.jmst.2016.09.018

${ }^{17}$ J. Xu, B. Guan, H. H. Yu, X. Z. Cao, Y. C. Xin, Q. Liu, Effect of twin boundary-dislocation-solute interaction on de twinning in a Mg-3Al-1Zn Alloy, J. Mater. Sci. Technol., 32 (2016), 1239-1244, doi:10.1016/j.jmst.2016.08.023

${ }^{18}$ S. A. Khan, M. S. Bhuiyan, Y. Miyashita, Y. Mutoh, T. Koike, Corrosion fatigue behavior of die-cast and short-blasted AM60 magnesium alloy, Mater. Sci. Eng. A, 528 (2011), 1961-1966, doi:10.1016/ j.msea.2010.11.033

${ }^{19}$ S. Rozali, Y. Mutoh, K. Nagata, Effect of frequency on fatigue crack growth behavior of magnesium alloy AZ61 under immersed 3.5 mass $\% \mathrm{NaCl}$ environment, Mater. Sci. Eng. A, 528 (2011), 2509-2516, doi:10.1016/j.msea.2010.12.048
${ }^{20}$ Z. B. Sajuri, Y. Miyashita, Y. Mutoh, Effect of humidity and temperature on the fatigue behavior of an extruded AZ61 magnesium alloy, Fatigue. Fract. Eng. M, 28 (2005), 373-379, doi:10.1111/ j.1460-2695.2005.00775.x

${ }^{21}$ M. S. Bhuiyan, Y. Mutoh, T. Murai, S. Iwakami, Corrosion fatigue behavior of extruded magnesium alloy AZ80-T5 in a $5 \% \mathrm{NaCl}$ environment, Eng. Fract. Mech, 77 (2010), 1567-1576, doi:10.1016/ j.engfracmech.2010.03.032

${ }^{22}$ I. J. Polmear, Magnesium alloys and applications, Mater. Sci. Tech-Lond, 10 (1994), 1-16, doi:10.1179/mst.1994.10.1.1

${ }^{23}$ M. Easton, W. Qian, B. Song, T. Abbott, A comparison of the deformation of magnesium alloys with aluminium and steel in tension, bending and buckling, Materials and Design, 27 (2006), 935-946, doi:10.1016/j.matdes.2005.03.005

${ }^{24}$ D. Wan, J. Wang, L. Lin, Z. Feng, G. Yang, Damping properties of Mg-Ca binary alloys, Physica B, 403 (2008), 2438-2442, doi:10.1016/j.physb.2008.01.008

${ }^{25}$ Z. Ma, H. Zhao, M. Zhou, H. Cheng, X. Ma, X. Du, L. Ren, Elastic-plastic bending properties of an AZ31B magnesium alloy based on persistent tensile preloads, Journal of Alloys and Compounds ,708 (2017), 594-599, doi:10.1016/j.jallcom.2017.03.038

${ }^{26}$ Z. Li, H. Zou, J. Dai, X. Feng, M. Sun, L. Peng, A comparison of low-cycle fatigue behavior between the solutionized and aged Mg-3Nd-0.2Zn-0.5Zr alloys. Mater. Sci. Eng. A., 695 (2017), 342-349, doi:10.1016/j.msea.2017.04.047

${ }^{27}$ L. Tana, X. Zhang, Q. Suna, J. Yua, G. Huanga, Q.Liua, Pyramidal slips in high cycle fatigue deformation of a rolled $\mathrm{Mg}-3 \mathrm{Al}-1 \mathrm{Zn}$ magnesium alloy, Mater. Sci. Eng A, 699 (2017), 247-253, doi:10.1016/j.msea.2017.05.092

${ }^{28}$ H. Mayer, M. Papakyriacou, B. Zettl, S. E. Stabzl-Tschegg, Influence of porosity on the fatigue limit of die cast magnesium and aluminum alloys, Int. J. Fatigue, 25 (2003), 245-256, doi:10.1016/S01421123(02)00054-3

${ }^{29}$ A. A. Luo, Magnesium casting technology for structural applications, J. Magnes. Alloys, 1 (2013), 2-22, doi:10.1016/j.jma.2013. 02.002

${ }^{30}$ J. F. Wang, P. F. Song, S. Huang, F. S. Pan, High strength and good ductility Mg-RE-Zn-Mn Magnesium alloy with Long-period stacking ordered phase, Mater. Lett, 93 (2013), 415-418, doi:10.1016/j.matlet.2012.11.076

${ }^{31}$ O.P. Khanna, Material Science \& Metallurgy, India, 2016

${ }^{32}$ M. F. Ashby, Material selection in Mechanical Design, $3^{\text {rd }}$ ed., Elsevier, India, 2009

${ }^{33}$ D. R. Ni, D. Wang, A. H. Feng, G. Yao, Z. Y. Ma, Enhancing the high-cycle fatigue strength of Mg-9Al-1Zn casting by friction stir processing, Scr. Mater, 61 (2009), 568-571, doi:10.1016/ j.scriptamat.2009.05.023

${ }^{34}$ Q. Huo, X. Yang, J. Ma, H. Sun, J. Wang, L. Zhang, Texture weakening of AZ3113 Magnesium alloy sheet obtained by a combination of bidirectional cyclic bending at low temperature and static recrystallization, J. Mater. Sci, 48 (2013), 913-919, doi:10.1007/ s10853-012-6814-3

${ }^{35}$ Y. Kawamura, K. Hayashi, A. Inoue, T. Masumoto, Rapidly solidified powder metallurgy $\mathrm{Mg}_{97} \mathrm{Zn}_{1} \mathrm{Y}_{2}$ alloys with excellent tensile yield strength above $600 \mathrm{Mpa}$, Mater. Trans, 42(2001), 1171-1174

${ }^{36}$ J. Ma, X. Yang, Q. Huo, H. Sun, J. Qin, J. Wang, Mechanical properties and grain growth kinetics in magnesium alloy after accumulative compression bonding, Mater. Des, 47 (2013) 505-509, doi:10.1016/j.matdes.2012.12.039

${ }^{37}$ B. L. Mordike, T. Ebert, Magnesium-properties-applicationspotential, Mater. Sci. Eng. A, 302 (2001), 37-45, doi:10.1016/ S0921-5093(00)01351-4

${ }^{38}$ F. Yang, F. Lv, X. M. Yang, S. X. Li, Z. F. Zhang, Q. D. Wang, Enhanced very high cycle fatigue performance of extruded Mg-12Gd-3Y-0.5Zr magnesium alloy, Mater. Sci. Eng. A, 528 (2011), 2231-2238, doi:10.1016/j.msea.2010.12.092 
${ }^{39}$ X. Yang, Y. Okabe, H. Miura, T. Sakai, Annealing of a magnesium alloy AZ31after interrupted cold deformation, Mater. Des, 36 (2012), 573-579, doi:10.1016/j.matdes.2012.08.025

${ }^{40}$ L. Jiang, W. Liu, G. Wu, W. Ding, Effect of chemical composition on the microstructure, tensile properties and fatigue behavior of sand -cast Mg-Gd-Y-Zr alloy, Mater. Sci. A, 612 (2014), 293-301, doi:10.1016/j.msea.2014.06.049

${ }^{41}$ D. R. Ni, D. Wang, A. H. Feng, G. Yao, Z.Y, Ma, Enhancing the high- cycle fatigue strength of Mg-9Al-1Zn casting by stir processing, Sci. Mater., 61 (2009), 568-571, doi:10.1016/j.scriptamat. 2009.05.023

${ }^{42}$ G. Huang, J. Li, T. Han, H. Zhang, F. Pan, Improving low-cycle fatigue properties of rolled AZ31 magnesium alloy by pre-compression deformation, Mater. Des, 58 (2014), 439-444, doi:10.1016/ j.matdes.2014.01.075

${ }^{43}$ P. Li, G. Wu, R. Xu, W. Wang, S. Wu, K. W. K. Yeung, P. K. Chu, In vitro corrosion inhibition on biomedical shape memory alloy by plasma - polymerized allay mine film, Mater. Lett, 89 (2012), 51-54, doi:10.1016/j.matlet.2012.08.054

${ }^{44}$ A. Saravanan, P. Suresh, Static analysis and weight reduction of aluminum casting clloy connecting rod using finite element method, International Journal of Mechanical and production Engineering Research and Development, 8 (2018), 507-518, doi:10.24247/ ijmperdjun 201855

${ }^{45} \mathrm{G}$. Song, Control of biodegradation of biocompatible magnesium alloys, Corros. Sci, 49 (2007), 1696-1701, doi:10.1016/j.corsci. 2007.01.001

${ }^{46}$ X. N. Liao, F. Y. Cao, L. Y. Zheng, W. J. Liu, A.Chen, J. Q. Zhang, C. Cao, Corrosion behavior of copper under chloride-containing thin electrolyte layer, Corros Sci, 53 (2011), 3289-98, doi:10.1016/ j.corsci.2011.06.004

${ }^{47}$ F. Witte, V. Kaese, H. Haferkamp, E. Switzer, A. Meyer-Lindenberg, C. J. Wirth, H. Windhagan, In vivo corrosion of four magnesium alloys and the associated bone response, Biomaterials, 26 (2005), 3557-3563, doi:10.1016/j.biomaterials.2004.09.049

${ }^{48}$ U. Riaz, C. Nwaoha, S. M. Ashraf, Recent advances in corrosive protective composite coatings based on conductive polymers and natural resources derived polymers, Prog. Org. Coat, 77 (2014), 743-756, doi:10.1016/j.porgcoat.2014.01.004

${ }^{49}$ M. P. Staiger, A. M. Pietak, J. Huadmai, G. Dias, Magnesium and alloys as orthopedic biomaterials: A review, Biomaterials, 27 (2006), 1728-1734, doi:10.1016/j.biomaterials.2005.10.003

${ }^{50}$ C. Q. Li, D. K. Xu, B. J.Wang, L.Y. Sheng, E. H. Han, Suppressing effect of Heat treatment on the Portevin- Le Chatelier Phenomenon of Mg-4Li- 6\%Zn- 1.2\% Y Alloy, J. Mater. Sci. Technol, 32 (2016), 1232-1238, doi:10.1016/j.jmst.2016.09.018

${ }^{51}$ G. Wu, J. M. Ibrahim, P. K.Chu, Surface design of biodegradable magnesium alloys- a review, Surf. Coat. Technol., 233 (2013), 2-12, doi:10.1016/j.surfcoat.2012.10.009

${ }^{52}$ Oak Ridge National Laboratory, Transportation Energy Data Book, $34^{\text {th }}$ ed., Oak Ridge, TN, Oak Ridge National Laboratory, http://cta.ornl.gov/data/chapter4.shtml, 28.09.2015

${ }^{53}$ M. Haghshenas, Mechanical characteristics of biogradable magnesium matrix composites: a review, Journal of magnesium alloy, (2017), 2213-9567, doi:10.1016/j.jma.2017.05.001

${ }^{54}$ US Geological Survey, Mineral Commodity Summaries, Aluminum, http://minerals.usgs.gov/minerals/pubs/commodity/aluminum/mcs-2 015-alumi.pdf, 30.01.2015

${ }^{55}$ US. Geological Survey, Mineral Commodity Summaries, Magnesium Metal, http://minerals.usgs.gov/minerals/pubs/commodity/magnesium/mcs-2015-mgmet.pdf, 30.01.2015 -

${ }^{56}$ A. Saravanan, P. Suresh ,V. Arthanari, S. Nethaji, S. Muthukumar, Design and analysis of trestle hydraulic jack using finite element method, International Journal of Mechanical and production Engineering Research and Development, 08 (2018), 437-448, doi:10.24247/ijmperddec201848 